\title{
PEMANFAATAN WARNA PADA POSTER BUKU CERITA BERGAMBAR SEJARAH PURA PULAKI
}

\author{
Nyoman Maruta Gautama, Hendra Santosa, I Wayan Swandi \\ Institut Seni Indonesia Denpasar
}

\begin{abstract}
Abstrak. Artikel ini membahas tentang warna yang digunakan dalam penciptaan poster dari buku cerita bergambar sejarah Pura Pulaki ditinjau dari teori warna Brewster. Pokok bahasan meliputi dua bagian, yaitu karakter warna yang digunakan dalam desain poster dan pengaruh warna yang dipakai untuk mendukung fungsi poster. Tujuannya adalah untuk mengetahui penggolongan karakter warna yang terdapat pada poster cerita bergambar sejarah Pura Pulak dan mengetahui pengaruh dari penggunaan kombinasi warna panas dan dingin pada poster cerita bergambar sejarah Pura Pulaki. Penelitian ini menggunakan metode penciptaan transformasi dengan melakukan observasi, wawancara dan kepustakaan tentang media promosi poster dan warna yang dipakai. Hasil menunjukkan bahwa poster buku cerita bergambar sejarah Pura Pulaki menggunakan dua jenis warna yaitu warna panas pada bagian tengah poster sedangkan warna dingin digunakan pada bagian pinggir poster digital. Kombinasi warna dingin dan warna panas tersebut menghasilkan warna yang kontras. Kontras warna membuat perbedaan yang jelas antara unsur-unsur poster yang ada, sehingga mudah untuk dibaca bagi yang melihatnya.
\end{abstract}

Kata Kunci : warna, poster, cerita bergambar, pura pulaki

\begin{abstract}
This article discusses the colors used in creating posters from Pura Pulaki historical picture books in terms of Brewster's color theory. The subject covers two parts, namely the color character used in the poster design and the effect of the colors used to support the poster function. The aim is to find out the color character classification found on the Pura Pulaki historical picture posters and find out the effect of using hot and cold color combinations on Pulaki Temple's historical picture posters. This study uses the method of creating transformation by conducting observations, interviews, and literature on poster promotion media and colors used. The results show that the Pura Pulaki historical picture book poster uses two types of colors, namely hot colors on the center of the poster while cold colors are used on the edge of the digital poster. The combination of cold and hot colors produces a contrasting color. The color contrast makes a clear difference between the elements of the poster, so it's easy to read for those who see it.
\end{abstract}

Keyword: Color, Poster, Drawing Stories, Pura Pulaki

Correspondence author: Hendra Santosa, hendrasnts@gmail.com, Bali, Indonesia 


\section{Pendahuluan}

Media poster merupakan suatu media promosi yang sering digunakan masyarakat umum sebagai media penyampai sebuah pesan. Seperti beberapa pengertian poster berikut secara keseluruhan menyangkut tentang pemilik pesan (komunikator) menggunakan media poster sebagai perantara kepada penerima pesan (komunikan) menggunakan visual yang menarik dengan tujuan tertentu. Tujuannya bervariasi seperti misalnya dugunakan untuk promosi barang atau jasa, tujuan pendidikan, himbauan kepada masyarakat dan yang lainnya.

Menurut Anitah, poster adalah sebuah media bergambar kombinasi dari unsur-unsur visual seperti garis, gambar dan kalimat untuk menyampaikan sebuah pesan dengan singkat dan menarik (Anitah). Kombinasi unsur-unsur visual poster haruslah serasi, agar tidak kontras satu dengan yang lainnya. Keserasian kombinasi unsur-unsur visual poster tersebut dapat diatur dengan penempatan atau tata letak (layout) unsur-unsur visualnya. Kombinasi unsur-unsur visual poster yang diatur dengan baik menjadikan terlihat serasi, sehingga membuat tampilannya menjadi menarik perhatian audiens. Teks yang terdapat pada poster menjadi dapat dengan mudah dibaca dengan didukung pemilihan jenis huruf dan warna yang dipakai. Ilustrasi gambar yang mengilustrasikan pesan yang terkandung dalam poster mendukung teks yang terdapat pada poster, membuat mudah dibaca atau dimengerti oleh penerima pesan atau audiens (komunikan). Dengan adanya kombinasi yang serasi dari unsur-unsur visual tersebut membuat pesan yang terdapat pada poster dapat dikomunikasikan dengan baik kepada audiens (komunikan), sehingga fungsi poster sebagai media gambar untuk menarik perhatian dan penyampaian pesan dapat berfungsi dengan baik.

Media poster mempunyai nilai guna lebih dalam menarik target atau audiens yang memiliki minat sesuai dengan pesannya karena pesan yang ada di dalamnya menyangkut pokok permasalahan (Lawson). Poster digunakan sebagai media promosi karena dapat diaplikasikan diberbagai media ditempat-tempat umum. Penempatan poster di tempat umum atau keramaian memudahkan untuk menyampaikan pesan kepada sasaran yang mempunyai minat terhadap informasi yang terdapat pada poster. Komunikator tidak harus mengaplikasikan poster ditempat tertentu untuk mencari target audiens atau konsumen yang sesuai dengan informasi pada poster tersebut. Dengan mengaplikasikannya di tempat umum, maka target audiens atau konsumen akan melihat sendiri poster yang dipasang, dengan kata lain target audiens yang menghampiri sendiri poster tersebut. Sangat dimungkinkan juga untuk menarik perhatian audiens diluar target sasaran, karena tertarik dengan informasi atau pesan yang terdapat pada poster.

Untuk menarik perhatian target audiens (komunikan) agar berminat dengan informasi atau pesan yang ditawarkan lewat media poster tentunya tampilan poster tersebut harus memiliki tampilan menarik agar dapat menyampaikan informasi atau pesan secara ringkas langsung pada intinya. Seperti yang telah dijelaskan pada paragraf sebelumnya, pengaplikasian media poster lebih banyak dilakukan di tempat umum yang dekat dengan target audiens. Kegiatan yang beragam dilakukan oleh audiens di tempat umum tersebut tidak memungkinkan untuk memperhatikan terus menerus media poster yang diaplikasikan disana. Media poster yang diaplikasikan harus menampilkan kombinasi unsur-unsur visual yang menerangkan pokok permasalahan atau pesan yang ingin disampaikan. Ketika audiens atau komunikan melewati poster perhatiannya menjadi teralihkan dengan tampilan poster tersebut. Ketika target audiens melihat, dari tampilan visual poster yang disajikan audiens dengan mudah dapat dengan cepat membaca informasi atau pesan yang disajikan. 
Media promosi poster harus menarik untuk dibaca sampai membuat audiens yang melihat berhenti berjalan saat melewatinya atau disebut eye-catching (Huddle). Poster cerita bergambar sejarah Pura Pulaki merupakan salah satu media promosi yang digunakan untuk mempromosikan produk buku cerita bergambar tentang sejarah dari Pura Pulaki. Untuk dapat mempromosikan dengan baik, maka sangat perlu membuat poster yang mampu menarik perhatian audiens. Jika audiens tertarik melihat poster tersebut, maka ada kemungkinan untuk dibaca. Sehingga pesan yang terdapat pada poster tersampaikan kepada audiens dengan kata lain tujuan menggunakan poster untuk promosi dapat terwujud.

Salah satu faktor yang membuat sebuah media dapat mengkomunikasikan pesannya adalah cara media tersebut membuat audiens tertarik dan paham dengan pesan yang ingin disampaikan (Hamida et al.). Seperti media Desain Komunikasi Visual lainnya, dalam merancang sebuah poster juga harus memperhatikan unsur-unsur desain penyusunnya agar dapat menarik perhatian audiens, salah satunya adalah warna. Warna merupakan salah satu unsur penyusun sebuah desain yang penting dalam menentukan respon dari orang. Respon audiens terhadap warna akan memberikan kesan dan identitas tertentu kepada yang melihat sesuai dengan latar belakang mereka maisng-masing.

Dalam pemilihan warna huruf dan latar belakang pada poster hendaknya dibuat kontras agar mudah dibaca, sehingga menekankan pesan pada poster secara khusus (Anitah). Pemilihan warna kontras pada media promosi poster sangat mempengaruhi tampilan visual poster yang dilihat oleh audiens. Pendapat tersebut juga sejalan dengan penelitian yang dilakukan oleh Icca Stella Amalia terhadap poster yang ada di Puskesmas Talaga. Pengunjung Puskesmas Talaga memberikan pendapat bahwa warna tidak kontras yang diaplikasikan pada poster yang dipasang kurang membantu dalam membaca. Seharusnya menggunakan warna latar dan huruf yang kontras agar memperjelas huruf pada poster, sehingga mudah dibaca (Amalia).

Seperti yang dijelaskan pada buku Warna : Teori dan Kreativitas Penggunaannya oleh Sulasmi Darmaprawira W.A, secara garis besar sifat warna ada dua golongan besar, yaitu warna panas dan warna dingin. Dalam lingkaran warna, warna - warna disekitar warna jingga atau merah termasuk warna panas atau hangat dan sebaliknya yang dekat dengan warna biru kehijauan masuk kedalam golongan warna dingin atau sejuk (Darmaprawira).

Kedua golongan besar warna tersebut berdasarkan dua alasan simbolisnya, yaitu:

1. Golongan warna merah sering diasosiasikan dengan benda-benda yang memberi kesan panas seperti matahari, darah dan api. Warna-warna yang merangsang emosi kejiwaan tersebut dimulai dari warna merah, jingga kuning sampai kuning kehijauan dan merah keunguan. Sebaliknya, golongan warna yang memberikan kesan sejuk menenangkan emosi kejiwaan adalah warna dari langit, gunung di kejauhan dan warna air dingin pada umumnya (Darmaprawira).

2. Warna yang terlihat oleh mata seolah menimbulkan efek panas atau dingin secara langsung terhadap badan yang melihat. Warna merah memicu emosi tinggi pada yang melihat dibandingkan dengan warna lainnya, sebaliknya warna biru menenangkan jiwa yang melihat. Warna merah dan kuning lebih banyak dapat memantulkan cahaya dibandingkan dengan warna hijau dan biru (Darmaprawira).

Penggunaan warna pada poster cerita bergambar sejarah Pura Pulaki yang bersifat dingin dan warna yang bersifat panas bertujuan untuk membuat sebuah kombinasi warna yang dapat menimbulkan kontras. Kombinasi warna panas dan warna dingin yang digunakan pada poster membuat perbedaan bagian antara unsur-unsur yang terdapat pada poster. Ilustrasi, tipografi, teks, komposisi yang digunakan menjadi terlihat jelas. 
Kontras warna yang dihasilkan dari kombinasi warna berkarakter panas dan warna yang berakarter dingin membuat tampilan visual poster menjadi mencolok. Poster dengan tampilan mencolok mudah untuk menarik perhatian audiens atau komunikan dari perhatian bidang sekitar poster atau dari media promosi poster lainnya. Dengan dapat menarik perhatian audiens tersebut maka kemungkinan untuk diperhatikan atau dibaca menjadi lebih besar, sehingga fungsi poster sebagai media promosi dapat tercapai dan pesan yang terdapat pada poster dapat tersampaikan kepada komunikan.

\section{Metode Penelitian}

Penelitian ini merupakan penciptaan dengan penyampaian deskriptif kualitatif yang menggunakan metode penciptaan transformasi dengan tahap pengumpulan data melalui observasi, wawancara dan kepustakaan untuk mendukung teorinya. Objek penciptaan adalah desain poster dari buku cerita bergambar sejarah Pura Pulaki yang digunakan sebagai media promosi kepada target audiens atau komunikan. Materi penelitian adalah warna yang dipakai pada media promosi poster cerita bergambar sejarah Pura Pulaki. Penggunaan warna pada desain menentukan tampilan visual dari desain poster buku cerita bergambar sejarah Pura Pulaki yang mendukung fungsi dari media poster tersebut.

Transformasi adalah penggambaran bentuk tentang karakter dengan cara memindahkan sebuah wujud atau figur ke objek yang digambar tanpa meninggalkan ciri khasnya (Kartika and Prawira). Teori Transformasi merupakan perubahan dari asli menjadi karya baru, yang bersumber dari pijakan latar belakang seni yang jelas. Ada tiga kategori transformasi, yaitu keterampilan teknis, nilai historis, gaib, dan mistik, berkaitan dengan terminologi taksu atau daya spiritual yang merasuki seniman ketika mengekspresikan diri. Pada proses penciptaan poster buku cerita bergambar sejarah Pura Pulaki ini adalah dalam mentransformasikan cerita dalam bentuk tulis maupun lisan ke bentuk visual media poster khususnya bagian warna (Budiapriliana et al.). Penciptaan media promosi poster cerita bergambar sejarah Pura Pulaki meliputi, yaitu :

1. Data primer.

Pengumpulan data primer untuk kebutuhan perancangan poster cerita bergambar tentang sejarah Pura Pulaki dilakukan dengan observasi dan wawancara. Observasi dilakukan dengan mengamati buku cerita tentang sejarah dari dibangunnya Pura Pulaki yang didapat dari narasumber, perpustakaan, toko buku dan internet dan pengamatan langsung di area Pura Pulaki untuk mendapatkan inspirasi, yang kemudian mentransformasikannya kedalam bentuk visual untuk menentukan tampilan visual pada poster terutama dalam bagian pewarnaan agar terlihat menarik. Sedangkan wawancara dilakukan kepada narasumber Ida Mangku Kade Temaja sebagai Ketua Pengempon Pura Pulaki untuk mendapatkan esensi dari cerita sejarah dibangunnya Pura Pulaki yang ditransformasikan kedalam bentuk ilustrasi untuk merancang visual dari media promosi poster terutama dalam pemilihan warna yang digunakan.

2. Data Sekunder.

Pengumpulan data sekunder untuk kebutuhan perancangan poster cerita bergambar tentang sejarah Pura Pulaki dilakukan dengan mengali melalui kepustakaan dan internet. Informasi yang dicari adalah data dan gambar yang dibutuhkan untuk mendukung penciptaan media poster cerita bergambar sejarah Pura Pulaki dari segi teorinya. Teori yang 
didapat digunakan dalam proses penciptaan sebagai acuan penciptaan poster tersebut khususnya dalam hal pemilihan warna.

Penciptaan media promosi poster ini dilakukan untuk mendukung promosi buku cerita bergambar Sejarah Pura Pulaki dengan memfokuskan pemilihan warna yang dipakai pada poster tersebut. Unsur warna dalam poster cerita bergambar sejarah Pura Pulaki difokuskan dalam penciptaan ini karena warna merupakan unsur visual yang sangat mempengaruhi perhatian orang yang melihat. Pemilihan warna untuk diaplikasikan dalam sebuah media promosi poster sangatlah penting. Menurut penelitian sebelumnya yang pernah dilakukan oleh Icca Stella Amalia tentang evaluasi media promosi poster hipertensi di Puskesmas Talaga yang mengatakan bahwa pengunjung tertarik pada poster hipertensi yang diaplikasikan tersebut karena warnanya terang, cerah, kontras dan bervariasi. Warna cerah yang diaplikasikan pada poster tersebut dinilai menarik perhatian mata, sehingga pengunjung Puskesmas Talaga dapat membaca poster dengan jelas (Amalia).

Sesuai dengan kegunaan dari poster sebagai media promosi untuk menarik perhatian audiens atau komunikan, penggunaan warna yang dapat menarik perhatian sangat diperlukan. Hal tersebut dapat berpengaruh terhadap keefektifan poster dalam menarik perhatian audiens atau komunikan, sehingga pesan yang terdapat pada poster tersampaikan dengan jelas kepada pembaca.

Pengumpulan data dilakukan dengan observasi pada sumber pustaka dan area Pura Pulaki untuk mendapatkan data sebagai bahan merancang media poster. Selain itu wawancara dengan narasumber Ida Mangku Kade Temaja sebagai Ketua Pengempon Pura Pulaki dilakukan untuk menambah data dan menggali inspirasi dalam menentukan rancangan media poster. Data-data yang didapat tersebut ditransformasikan kedalam bentuk desain poster buku cerita bergambar sejarah Pura Pulaki dan didukung sumber kepustakaan sebagai teori pendukungnya khususnya dalam bagian pengaplikasian warna yang dipakai. Dalam membahas warna tersebut menggunakan literatur-literatur dari buku dan jurnal tentang media promosi poster dan warna. Pengumpulan literatur yang berhubungan dengan objek penelitian tersebut dilakukan untuk menunjang materi penelitian.

Warna yang diaplikasikan pada desain poster cerita bergambar sejarah Pura Pulaki digolongkan menjadi dua bagian, yaitu warna yang tergolong dalam sifat panas dan warna yang dugolongkan dalam sifat warna dingin. Penggolongan warna tersebur berpatokan pada teori Brewster. Warna dibagi menjadi dua bagian ekstrim, yaitu warna panas dan warna dingin. Warna panas dimulai dari warna merah sampai hijau kekuningan sedangkan warna dingin dimulai dari warna hijau sampai ungu kemerahan. Penggunaan warna panas dan warna dingin tersebut menghasilkan kombinasi warna yang mencolok, sehingga menarik perhatian pembaca.

\section{Hasil dan Pembahasan}

\section{Poster}

Poster adalah media publikasi yang di dalamnya terdapat unsur tulisan dan gambar yang dikombinasikan dengan tujuan menginformasikan kepada target sasaran atau audiensnya. Media poster diaplikasikan ditempat umum seperti sekolah, kantor, pasar, mall dan tempattempat strategis lainnya untuk mengajak target sasaran atau audiens sesuai dengan informasi yang ada pada poster ( $\underline{\text { Samin }}$ ). Tulisan dan gambar saling mendukung satu dengan yang lain untuk menghasilkan kombinasi yang dapat mengantarkan pesan dengan baik kepada audiens. 
Pesan yang disampaikan dapat ditujukan kepada audiens tertentu atau bahkan untuk umum, sehingga penempatannya ditempatkan ditempat-tempat strategis agar dapat dilihat lebih banyak oleh audiens yang dituju.

Menurut Rahmaniati poster merupakan sebuah media promosi yang menggabungankan gambar dan tulisan singkat dalam satu bidang dengan memperhatikan nilai-nilai estetis dalam perancangannya untuk dapat menarik perhatian audiens. Fungsi poster sebagai media promosi penyalur informasi dapat memberi tekana pada ide pokoknya yang bersifat mengajak, memberi saran atau memperkenalkan sesuatu kepada audiens, sehingga dapat dimengerti dengan melihatnya sepintas. Selain dapat menarik perhatian, poster juga mampu mempengaruhi dan memotivasi tingkah laku audiens yang melihatnya (Rahmaniati).

Putraka mengatakan dalam penelitiannya bahwa warna sangat penting pada tampilan sebuah poster dalam meyampaikan sebuah pesan, mengingat media promosi poster merupakan media yang sangat efektif digunakan untuk menyampaikan suatu informasi baik yang bersifat komersil atau non komersil (Putraka). Dalam penelitiannya juga dikatakan respon seseorang ditentukan oleh warna yang dilihat, karena audiens atau masyarakat hal pertama yang dilihat adalah warna (Putraka).

Dibuatnya sebuah media poster memiliki maksud dan tujuannya. Tujuan dari media poster umumnya sebagai media publikasi agar masyarakat mengetahui informasi sesuai dengan yang ada dalam poster tersebut. Secara khusus media poster memiliki tujuan dibuatnya yang menyesuaikan dengan tujuan pembuatnya (Samin). Untuk dapat mewujudkan tujuan dari dibuatnya poster tersebut harus memperhatikan bagaimana tampilan poster yang akan dipublikasikan kepada audiens atau masyarakat agar pesan yang ada pada poster dapat tersampaikan dengan baik.

Poster cerita bergambar sejarah Pura Pulaki merupakan media publikasi yang bertujuan untuk promosi. Poster tersebut dibuat untuk mempromosikan produk sebuah buku cerita bergambar yang menceritakan tentang sejarah bagaimana asal mula dibangunnya Pura Pulaki. Berdasarkan tujuan utama poster, yaitu untuk dapat menarik perhatian audiens sehingga tujuan mempromosikan sesuatu dalam hal ini buku cerita bergambar sejarah Pura Pulaki dapat tercapai diperlukan tampilan poster yang menarik. Hal utama yang dapat menarik perhatian dari audiens dalam sebuah desain media promosi poster adalah warna, karena warna merupakan bagian pertama dari tampilan visual sebuah desain media promosi yang terlihat oleh mata. Warna yang digunakan dalam media promosi poster cerita bergambar sejarah Pura Pulaki adalah kombinasi warna yang berkarakter panas dan dingin. Warna berkarakter panas dan dingin disusun atau dikombinasikan berdampingan, menampilkan warna yang mencolok atau kontras dan mendukung tampilan unsur-unsur visual yang ada pada poster sehingga terlihat jelas.

\section{Warna}

Warna adalah spektrum pada cahaya putih (Nugroho). Warna merupakan bagian dari sifat cahaya yang dipancarkan yang menjadi pengalaman indra penglihatan seseorang. Sebagai bagian dari pengalaman indra penglihatan, warna yang ditangkap oleh indra penglihatan tersebut merupakan pantulan cahaya dari suatu benda yang ada disekitar kemudian ditangkap oleh indra penglihatan sesuai dengan panjang gelombang cahaya. Sebagai contohnya, warna biru memiliki panjang gelombang sekitar 460 nanometer, sedangkan warna kuning memiliki gelombang sekitar 650 nanometer (Solso et al.).

Lingkaran warna merupakan sistem warna yang menggunakan sebutan warna dengan istilah yellow (kuning), red (merah), dan blue (biru). Lingkaran warna merupakan salah satu sistem warna selain RGB dan CMYK. Lingkaran warna dapat memudahkan seseorang dalam 
melakukan pembelajaran mengenai warna. Klasifikasi warna dapat dikelompokkan menjadi 3, diantaranya adalah :

1. Warna Primer Warna primer merupakan warna-warna yang paling kuat. Warna primer merupakan warna utama pembentuk warna-warna lain disebut juga sebagai warna pokok (Putraka). Terciptanya warna primer karena warna tersebut tidak dapat dibentuk dari warna lain artinya, warna primer merupakan warna asli dan tidak tercampur dengan warna lain. Selain itu, warna primer digunakan sebagai warna paling utama untuk memperoleh warnawarna primer adalah biru, merah, dan kuning.

\section{Warna Primer}

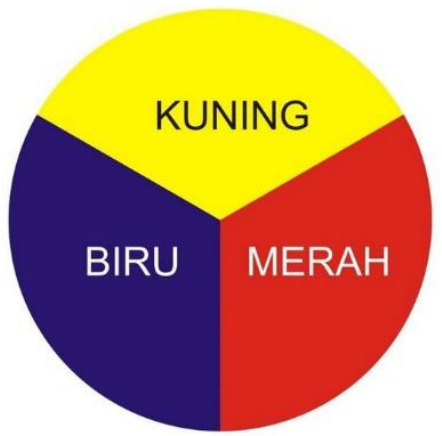

Gambar 1 Lingkaran Warna Primer.

Sumber: sekolahdesain.com (Reza, 2018)

2. Warna Sekunder Warna sekunder merupakan percampuran dua warna primer atau warna pokok (Putraka). Warna-warna sekunder diantaranya adalah orange, ungu, dan hijau.

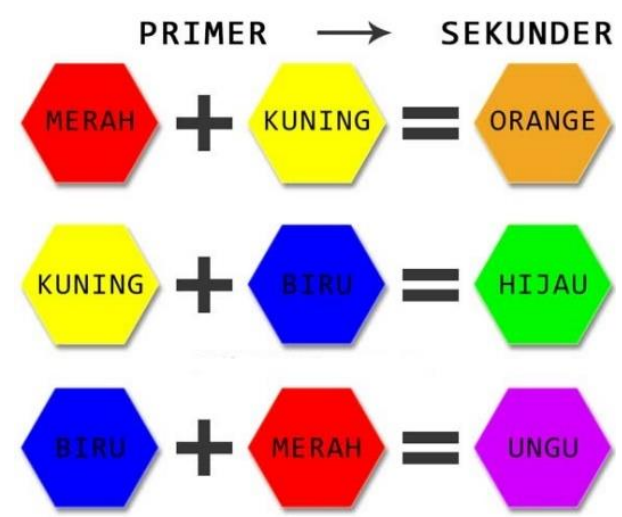

Gambar 2 Warna Sekunder.

Sumber : kuliahdesain.com (Bakekok, 2017)

3. Warna Tersier Warna tersier merupakan campuran satu warna primer dengan warna sekunder disebelahnya (Putraka). Warna tersier dapat dihasilkan juga dari percampuran dua warna sekunder. Warna tersier disebut juga warna ketiga. 


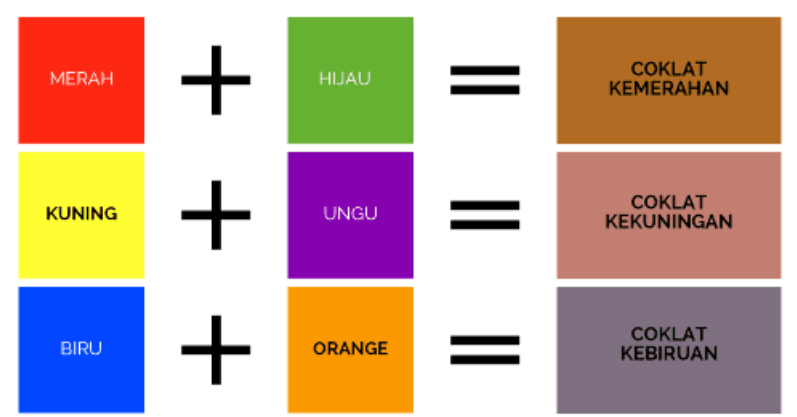

Gambar 3 Warna Tersier.

Sumber : bloggermas.com (Anas, 2016)

Warna-warna tersier di antaranya adalah coklat kuning, coklat merah, dan coklat biru Pembahasan warna jenis-jenis warna berdasarkan teori tiga warna primer, tiga warna sekunder, dan enam warna intermediate. Kedua belas warna ini kemudian disusun dalam satu lingaran warna yang biasa disebut dengan the color wheel.

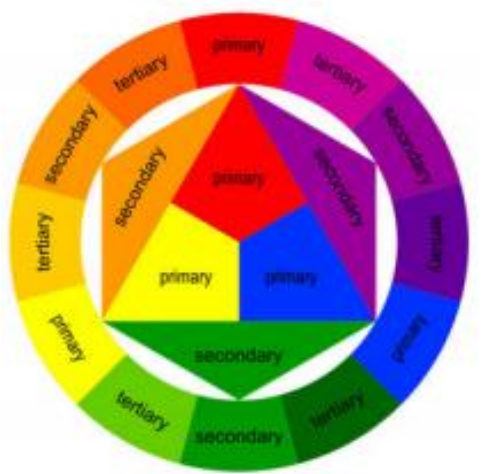

Gambar 4 Lingkaran Warna.

Sumber : warungstmj.com (Sodeq, 2017)

Lingkaran warna yang berisi dua belas warna dibagi menjadi dua bagian akan memperlihatkan setengah bagian tergolong dalam daerah warna yang bersifat panas dan setengah bagian yang lain menjadi daerah warna bersifat dingin.

\section{Warna Panas dan Warna Dingin}

Warna panas merupakan kelompok warna yang memiliki pengaruh panas sedangkan warna dingin adalah kelompok warna yang berpengaruh dingin terhadap kita. Warna panas memancarkan energi panas, sebaliknya warna dingin memancarkan energi dingin (Said). Jika dilihat dari masing-masing warna yang ada pada lingkaran warna, pembagian daerah warna panas dan dingin adalah sebagai berikut:

1. Golongan warna panas adalah merah (M), jingga kemerah-merahan (JM), jingga (J), jingga kekuning-kuningan (JK) dan kuning (K) digolongkan sebagai warna panas. Karena warnawara tersebut terkesan panas dan mempunyai efek yang panas. Warna paling panas adalah warna merah (M), jingga kemerah-merahan (JM) dan jingga (J).

2. Golongan warna dingin adalah warna ungu kemerahan-merahan (UM), ungu (U), ungu kebiru-biruan (UB), biru (B) dan hijau kebiru-biruan (HB) digolongkan sebagai warna dingin. Warna-warna yang masuk dalam bagian warna dingin tersebut dapat menimbulkan kesan dan efek yang dingin. Warna paling dingin adalah warna ungu (U), ungu kebiru-biruan (UB) dan biru (B). 
3. Adapun warna sedang atau warna yang tidak panas dan tidak dingin adalah warna hijau $(H)$, tetapi warna hijau dapat menjadi panas bila dicampur dengan warna kuning $(\mathrm{K})$ yang akan menjadi hijau kekuning-kuningan (HK). Sebaliknya warna Hijau dapat berubah menjadi dingin bila dicampur dengan biru (B) yang akan menjadi hijau kebiru-biruan (HB). Perubahan warna dingin menjadi hangat dapat dilihat lewat perubahan warna ungu (U). Ungu menjadi hangat jika berubah ke arah merah menjadi ungu kemerah-merahan (UM).

4. Kesan yang diberikan warna panas adalah kesan semangat, kuat, dan aktif. Sedangkan warna dingin memberikan kesan tenang, kalem, dan pasif.

Warna memberikan rangsangan bagi manusia agar lebih tertarik pada suatu hal. Hal tersebut yang membuat pikiran manusia terpengaruhi. Peranan warna dalam sebuah karya sangatlah penting, karena warna langsung berhubungan dengan hati pembuat karya maupun target audiens.

Penggunaan warna dalam sebuah desain grafis dapat digunakan untuk menarik perhatian, menghasilkan efek psikologis, mengembangkan asosiasi, membangun retensi dan menciptakan suasana yang menyenangkan. Perpaduan warna kontras yang disatukan membantu mempermudah penyampaian suatu pesan. Begitujuga sebaliknya warna yang senada dan warna yang terlalu banyak dapat membuat komunikasi tidak lancar (Amalia).

Warna dapat mempengaruhi jiwa dan emosi manusia dengan kuat yang dapat mempengaruhi hati seseorang, sehingga dapat menggambarkan hati dari seseorang itu. Dalam seni sastra baik lama dan modern puisi maupun prosa, dapat ditemui ungkapan-ungkapan tentang warna baik sebagai kiasan atau sebagai perumpamaan. Warna yang dapat mempengaruhi hati kegiatan fisik mental melalui berbagaiacam penelitian menyebutkan dipergunakan juga untuk alat penyembuhan penyakit mental (Darmaprawira).

Respons manusia terhadap warna merupakan tindakan yang bersifat alami seperti halnya mendengarkan sebuah musik yang gembira yang membuat hati senang atau musik sedih yang membuat hati juga menjadi sedih. Hal tersebut terjadi karena pengaruh terhadap mata seperti sekuat atau sesensitif bunyi yang mempengaruhi telinga (Darmaprawira).

Sifat warna panas dan warna dingin tercipta dari penggolongan ekstrem warna. Golongan warna panas adalah keluarga merah/jingga yang memiliki sifat dan pengaruh hangat, segar, menyenangkan, merangsang dan bergairah. Sedangkan golongan warna dingin adalah kelompok biru/hijau yang memiliki sifat dan penaruh sunyi, tenang, makin tua dan makin gelap mengarah ke suasana tenggelam dan depresi. Penggunaan warna dingin untuk ruangan memberi ilusi jarak yang membuat rasa tenggelam atau mundur. Sedangkan warna hangat yang termasuk kedalam keluarga merah memberikan kesan seolah - olah maju ke dekat mata dan menyempit.

Warna merupakan bagian pelengkap gambar yang dapat mewakili suasana kejiwaan pelukisnya dalam berkomunikasi. Warna juga dapat menyentuh kepekaan penglihatan sehingga mampu merangsang munculnya rasa sedih, haru, gembira, mood atau semangat, dan yang lainnya (Kusrianto). Dalam perancangan sebuah desainpun memperhatikan warna untuk dapat menimbulkan ketertarikan audiens lewat indra penglihatan yang merangsang rasa audiens tersebut, sehingga membuat audiens melihat sebuah desain yang dibuat dan membacanya dengan baik. Dengan munculnya rasa tertarik atau ingin tahu dari audiens terhadap sebuah desain membuat desain tersebut diperhatikan, pesan atau informasi yang terdapat pada desain tersampaikan kepada audiens yang melihat. 


\section{Poster Cerita Bergambar Sejarah Pura Pulaki}

Poster cerita bergambar Sejarah Pura Pulaki menggunakan warna panas dan warna dingin untuk menampilkan kontras warna pada tampilan visual poster. Selain itu untuk merangsang atau menarik perhatian audiens saat melihat tampilan poster. Dengan kombinasi warna panas dan dingin tampilan unsur-unsur visual poster terlihat jelas, sehingga dapat terbaca dengan jelas. Selain itu kombinasi warna panas dan dingin juga menarik perhatian audiens dengan warna-warna kontras yang ditampilkan.

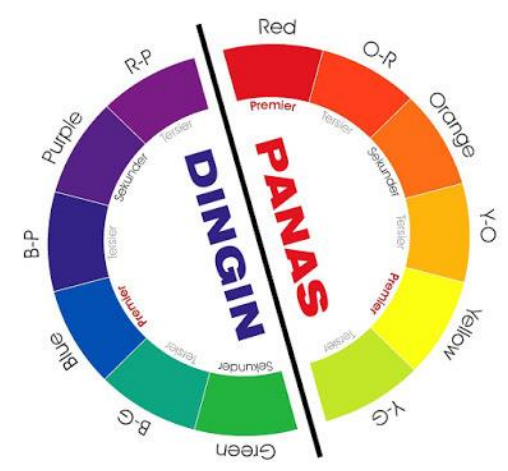

Gambar 5 Skema Warna Brewster

Sumber : grafis-media.website (St, 2018)

Penciptaan poster cerita bergambar sejarah Pura Pulaki, khususnya pada pemilihan warna yang dipkai berdasarkan dengan teori warna Brewster yang menggolongkan warna menjadi dua sifat, yaitu warna panas dan warna dingin. Sebenarnya temperatur warna tidak dapat diukur dengan alat pengukur suhu, karena yang dimaksud dengan suhu pada warna yang mengukur adalah rasa, bukan ukuran secara fisik (Darmaprawira). Skema warna panas dan dingin dapat dilihat pada skema warna yang diciptakan oleh Brewster, yaitu terdapat warna primer, warna tersier dan campuran warna sekunder, primer dan tersier.

Dari gabungan warna primer, sekunder, tersier dan campuran dari primer, sekunder dan tersier terbentuklah sebuah susunan warna yang terbagi menjadi 2 jenis yaitu warna panas dan dingin. Susunan warna dingin dimulai dari warna Hijau, Green-Blue (hijau kebiru - biruan), Biru, Biru ke unguan, Ungu, Merah keunguan. Sedangkan warna panas dimulai dari Yellow-Green (Hijau kekuningan), kuning, Yellow-Orange (Oranye kekuningan), Orange, Orange-Red (Merah keoranyean) dan merah.

\section{Warna Panas pada Poster Cerita Bergambar Sejarah Pura Pulaki.}

Pada lingkaran warna, warna kuning merupakan warna yang paling terang dan ungu adalah warna yang paling gelap. Pada skema warna psikologi, warna yang paling panas adalah warna jingga dan yang paling sejuk adalah warna biru-hijau. Deretan warna panas pada lingkaran warna dimulai dari MU(Merah-Ungu), M(Merah), MJ(Merah-Jingga), J(Jingga), KJ(KuningJingga), sampai K(Kuning) (Darmaprawira).

Pada poster cergam sejarah Pura Pulaki warna panas dominan digunakan pada ilustrasi bagian tengah pada poster, yaitu matahari, sinar, langit, daun-daun yang terkena sinar matahari dan teks bagian bawah. Berikut merupakan tampilan visual poster serta keterangan bagian yang menggunakan warna panas pada objeknya : 


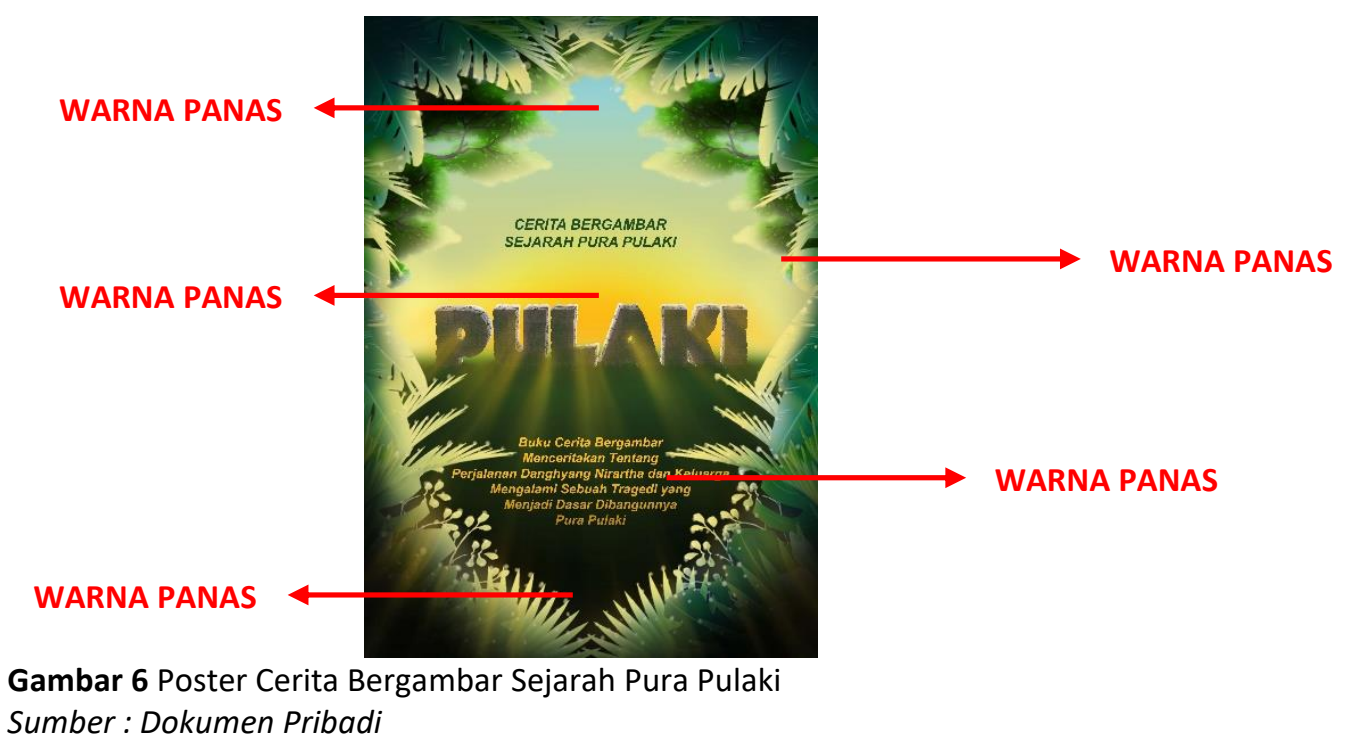

Pada poster cergam sejarah Pura Pulaki, dapat dilihat bahwa warna panas lebih dominan digunakan pada ilustrasi bagian tengah pada poster, yaitu matahari, sinar, langit, daun-daun yang terkena sinar matahari dan teks bagian bawah. Pada ilustrasi matahari warna yang dipakai adalah warna Kuning $(\mathrm{K})$ dan Jingga $(\mathrm{J})$ yang digradasikan untuk membuat warna yang mendukung ilustrasi matahari terbit dipagi hari. Sinar matahari menggunakan warna KuningJingga (KJ) untuk memberikan kesan pancaran sinar dari matahari pagi. Langit memakai warna Kuning (K) dibagian sekitar matahari untuk mendukung tampilan suasana pagi saat matahari terbit. Daun-daun yang terkena sinar menggunakan warna Kuning-Hijau (KH) dan teks bagian bawah menggunakan warna Jingga(J)

Secara keseluruhan sebagian besar warna panas berada pada bagian tengah poster. Matahari memakai warna panas untuk membuat kontras warna dengan ilustrasi susunan batu yang membentuk teks "PULAKI" dan padang rumput untuk memperjelas bentuk dari ilustrasi susunan batu berbentuk teks "PULAKI" yang berada diatas padang rumput sehingga jelas terbaca. ilustrasi susunan batu berbentuk teks "PULAKI" yang berada diatas padang rumput tersebut merupakan inti dari visual poster karena merupakan judul dari buku cerita bergambar yang dipromosikan, sehingga harus ditonjolkan dengan penggunaan warna panas dari ilustrasi matahari. Sinar matahari yang menggunakan warna panas bertujuan untuk mendukung tampilan dari ilustrasi matahari. Ilustrasi matahari lebih meyakinkan berada dibelakang ilustrasi bebatuan berbentuk teks "PULAKI". Selain itu juga membantu mempertegas bentuk ilustrasi bebatuan yang tersusun diatas rerumputan sehingga terlihat jelas oleh mata audiens. Langit menggunakan warna panas agar dapat menampilkan dengan jelas teks "CERITA BERGAMBAR SEJARAH PURA PULAKI" dan tumbuhan dibagian pinggir desain poster menggunakan warna panas untuk memperjelas bagian langit juga rerumputan. Teks deskripsi tentang produk buku cerita bergambar menggunakan warna panas yang kontras dengan warna rumput untuk memperjelas teks, sehingga mudah dibaca.

\section{Warna Dingin pada Poster Cerita Bergambar Sejarah Pura Pulaki.}

Pada lingkaran warna yang termasuk warna dingin atau sejuk adalah deretan warna mulai dari KH (Kuning-Hijau), H (Hijau), BH (Biru-Hijau), B (Biru), BU (Biru-Ungu) dan Ungu (Darmaprawira). Pada poster cergam sejarah Pura Pulaki warna dingin dominan digunakan pada ilustrasi pohon (kiri, kanan, atas dan bawah) poster, sebagian warna langit, rumput dan teks 
(judul \& teks bagian atas). Berikut merupakan tampilan visual poster serta keterangan bagian yang menggunakan warna panas pada objeknya :

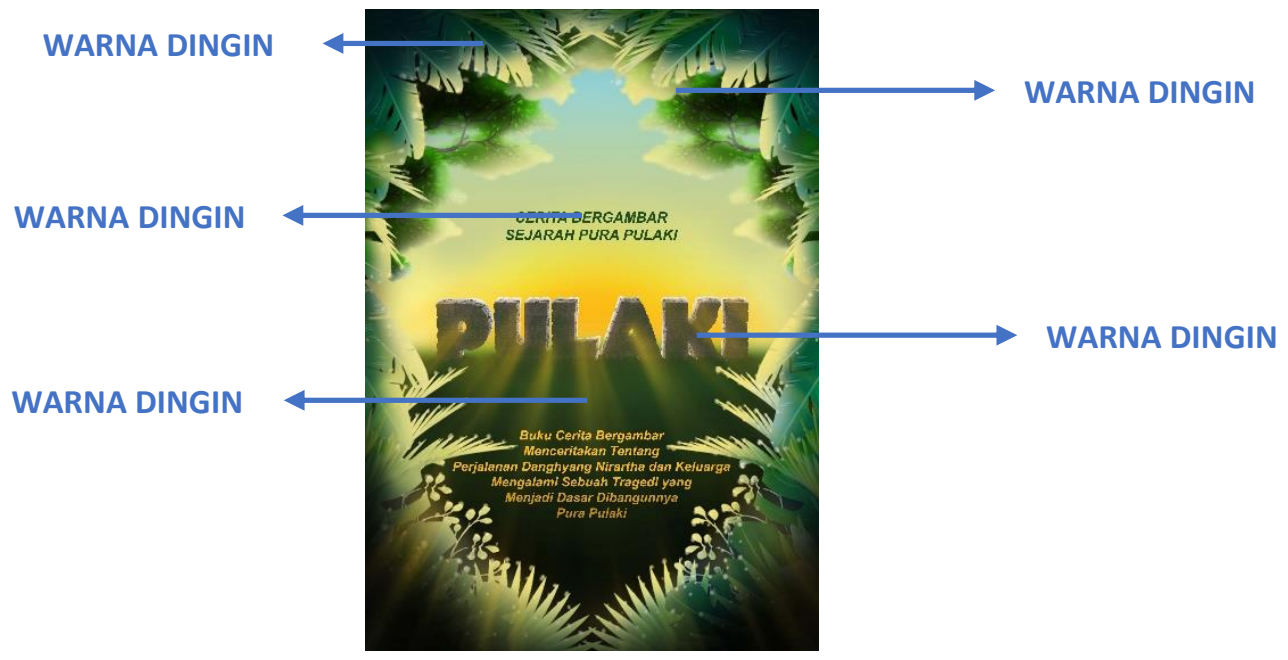

Gambar 7 Poster Cerita Bergambar Sejarah Pura Pulaki Sumber : Dokumen Pribadi

Pada poster cergam sejarah Pura Pulaki penggunaan warna dingin dominan pada ilustrasi pohon (kiri, kanan, atas dan bawah) poster, sebagian warna langit, rumput dan teks (judul \& teks bagian atas). Pada ilustrasi pohon (kiri, kanan, atas dan bawah) poster menggunakan warna Hijau $(H)$ untuk memunculkan suasana dalam hutan. Sebagian langit menggunakan warna Biru (B) tepatnya pada bagian atas. Rerumputan menggunakan warna $\mathrm{Hijau}(\mathrm{H})$ berbatasan langsung dengan langit dan ilustrasi matahari yang memakai warna panas. Judul buku berupa ilustrasi susunan batu berbentuk teks "PULAKI" menggunakan warna Abu dan Hijau yang dikombinasikan menampilkan kesan bebatuan alami yang berlumut. Teks keterangan bagian atasnya menggunakan warna $\mathrm{Hijau}(\mathrm{H})$ dibuat kontras dengan latar belakang langit pagi.

Penggunaan warna dingin pada poster sebagian besar ada pada bagian sisi posternya. Ilustrasi pohon yang ada pada bagian sisi poster memakai warna dingin untuk membuat kontras warna dengan ilustrasi langit pagi, sehingga bentuk ilustrasi pohon terlihat jelas untuk menampilkan kesan hutan. Sebagian warna langit menggunakan warna dingin terutama bagian atas untuk membuat kontras dengan warna ilustrasi pepohonan yang terkena sinar matahari pagi bagian atas poster. Sedangkan rumput menggunakan warna dingin untuk membuat kontras dengan warna ilustrasi pepohonan yang terkena sinar matahari pagi bagian bawah poster dan teks deskripsi tentang produk buku cerita bergambar yang meggunakan warna panas agar dapat terbaca dengan jelas. Teks "CERITA BERGAMBAR SEJARAH PURA PULAKI" pada bagian atas desain poster menggunakan warna dingin untuk memperjelas teks sehingga mudah dibaca.

\section{Warna Panas dan Dingin pada Poster Cerita Bergambar Sejarah Pura Pulaki.}

Pada poster cerita bergambar sejarah Pura Pulaki menggunakan kombinasi warna panas dan warna dingin. Kombinasi warna panas dan warna dingin menimbulkan komposisi warna yang kontras. Komposisi kontras suhu warna (panas dinginnya warna) merupakan komposisi yang meriah, dapat saling mengimbagi antara panas dan dingin sumali sembahyang ada aja.

Komposisi warna panas dominan digunakan pada ilustrasi dan teks bagian tengah poster, yaitu matahari, sinar, langit, daun-daun yang terkena sinar matahari dan teks bagian 
bawah. Penggunaan warna panas tersebut digunakan agar terlihat lebih mencolok dari warna dingin yang digunakan pada ilustrasi pohon (kiri, kanan, atas dan bawah) poster, sebagian warna langit, rumput dan teks (judul \& teks bagian atas). Begitu juga sebaliknya penggunaan warna dingin yang digunakan pada ilustrasi pohon (kiri, kanan, atas dan bawah) poster, sebagian warna langit, rumput dan teks (judul \& teks bagian atas) untuk terlihat kontras dengan bagian ilustrasi matahari, sinar, langit, daun-daun yang terkena sinar matahari dan teks bagian bawah pada poster yang menggunakan warna berkarakter panas.

Kontras suhu warna dapat digunakan untuk memberikan tampilan yang jelas antara tiap-tiap bagian unsur visual penyusun poster. Bagian ilustrasi dan teks yang terdapat pada poster terlihat dengan jelas batasnya masing-masing, sehingga fokus pembaca dapat terarah dengan baik. Ilustrasi yang mendukung teks pada poster dapat dengan baik memberikan gambaran mengenai pesan yang terdapat pada poster. Begitujuga sebaliknya teks yang terdapat pada poster dapat terbaca dengan baik. Sejalan dengan pendapat (Anitah) penulisan huruf dengan variasi warna juga dapat memberikan daya tarik tersendiri. Warna huruf yang kontras dengan latar belakang dari keseluruhan warna poster membantu untuk mempermudah keterbacaan.

Pemilihan warna panas dan dingin secara berdampingan dalam perancangan media poster cerita bergambar sejarah Pura pulaki bertujuan menarik audiens. Sesuai dengan penelitian yang pernah dilakukan Anitah, pengunjung berpendapat warna yang tidak terlalu kontras dan mencolok kurang membantu dalam membaca. Warna latar dan huruf yang kontras mempermudah pengunjung membaca dan pemperjelas huruf yang dibaca. Warna huruf dan latar belakang dibuat kontras supaya mudah dibaca maupun penekanan yang menghendaki penekanan khusus (Anitah).

Hal tersebut sesuai dengan penggunaan warna berkarakter panas dan dingin pada poster cerita bergambar sejarah Pura Pulaki yang digunakan untuk mempromosikan media buku cerita tentang sejarah dari dibangunnya Pura Pulaki. Kombinasi warna panas dan warna dingin yang diaplikasikan pada poster cerita bergambar sejarah Pura Pulaki mendukung fungsi dari media promosi poster untuk menarik perhatian audiens agar melihat dan membaca poster tersebut, sehingga pesan yang terdapat pada poster tersampaikan dengan baik kepada audiens dan tujuan untuk membuat buku cerita bergambar tentang sejarah Pura Pulaki sampai ketangan audiens dapat terwujud.

\section{Simpulan}

Warna memiliki sifat yang dibagi menjadi dua, yaitu warna panas dan warna dingin. Panas dinginnya warna yang dikatakan tidaklah dapat diukur secara fisik dengan alat pengukur suhu melainkan dengan rasa yang ditimbulkan saat warna tersebut dilihat oleh mata. Warna yang dilihat melalui penglihatan tersebut mampu merangsang munculnya rasa sedih, haru, gembira, mood atau semangat, dan termasuk rasa panas dan dingin.

Selain berpengaruh terhadap rasa dari audiens yang melihat, kombinasi warna panas dan dingin dapat menampilkan kontras yang menarik perhatian audiens yang melihat. Sesuai dengan tujuan digunakannya media poster yaitu untuk mempromosikan produk buku cerita bergambar tentang sejarah dibangunnya Pura Pulaki, warna kontras merupakan warna yang tepat digunakan.

Poster cerita bergambar sejarah Pura Pulaki menggunakan dua sifat warna dalam pewarnaannya, yaitu warna panas dan warna dingin. Warna panas dominan digunakan pada 
ilustrasi bagian tengah poster, yaitu matahari, sinar, langit, daun-daun yang terkena sinar matahari dan teks bagian bawah, sedangkan warna dingin dominan digunakan pada ilustrasi pohon (kiri, kanan, atas dan bawah), sebagian warna langit, rumput, ilustrasi bebatuan yang membentuk susunan huruf (judul cergam) dan teks bagian atas.

Komposisi kontras suhu warna (panas dinginnya warna) jika dikombinasikan dengan baik maka menciptakan kontras warna yang memperjelas tampilan visual pada masing-masing unsur visual yang ada pada poster. Kedua bagian dalam poster tersebut terlihat kontras satu dengan yang lainnya yang dipengaruhi oleh penggunaan warna panas dan dingin. Masingmasing bagian tersebut terlihat dengan jelas yang membuat audiens mudah dalam membacanya, sehingga pesan yang terdapat dalam poster tersampaikan dengan baik.

\section{Daftar Pustaka}

Amalia, Icca Stella. "Evaluasi Media Poster Hipertensi Pada Pengunjung Puskesmas Talaga Kabupaten Majalengka." KEMAS: Jurnal Kesehatan Masyarakat, vol. 9, no. 1, 2013, pp. 1-8, https://journal.unnes.ac.id/nju/index.php/kemas/article/view/2823.

Anitah, Sri. Media Pembelajaran. UNS press, 2008.

Budiapriliana, Luh et al. "Transformasi Prasi Tantri Carita Dalam Animasi Prasimotion." Prabangkara: Jurnal Seni Rupa dan Desain, vol. 21, no. 2, 2017, pp. 86-91, https://jurnal.isi-dps.ac.id/index.php/prabangkara/article/view/230.

Darmaprawira, Sulasmi. Warna: Teori Dan Kreativitas Penggunaannya. Penerbit ITB, 2002.

Hamida, Khairuna et al. "Penyuluhan Gizi Dengan Media Komik Untuk Meningkatkan Pengetahuan Tentang Keamanan Makanan Jajanan." KEMAS: Jurnal Kesehatan Masyarakat, vol. 8, no. 1, 2012, pp. 67-73, https://journal.unnes.ac.id/nju/index.php/kemas/article/view/2261.

Huddle, Penelope A. "How to Present a Paper or Poster." Journal of Chemical Education, vol. 77, no. 9, 2000, p. 1152, doi:https://doi.org/10.1021/ed077p1152.

Kartika, Dharsono Sony and Nanang Ganda Prawira. Pengantar Estetika. Rekayasa Sains, 2004. Kusrianto, Adi. Pengantar Desain Komunikasi Visual. Andi, 2007.

Lawson, Glenda. "The Poster Presentation: An Exercise in Effective Communication." Journal of Vascular Nursing, vol. 4, no. 23, 2005, pp. 157-158, doi:https://doi.org/10.1016/j.jvn.2005.09.001.

Nugroho, Eko. Pengenalan Teori Warna. Andi, 2008.

Putraka, Agus Ngurah Arya. "Warna Sebagai Pembentuk Estetika Pada Media Promosi Poster Dari Hoineken." Prabangkara: Jurnal Seni Rupa dan Desain, vol. 21, no. 1, 2017, pp. 1-4, https://jurnal.isi-dps.ac.id/index.php/prabangkara/article/view/162.

Rahmaniati, Rita. "Penggunaan Media Poster Untuk Meningkatkan Hasil Bel Ajar Ipa Peserta Didik Kelas Vb Sdn 6 Langkai Palangka Raya." Pedagogik Jurnal Pendidikan, vol. 10, no. 2, 2015, pp. 59-64.

Said, Abdul Azis. Dasar Desain Dwimatra. Universitas Negeri Makasar, 2006.

Samin, Cah. "Poster (Pengertian, Ciri, Tujuan, Jenis, Macam, Gambar)." 2016, https://www.artikelmateri.com/2016/03/poster-adalah-pengertian-ciri-tujuan-jenismacam-membuat-gambar.html.

Solso, Robert L et al. Cognitive Psychology. Pearson Education New Zealand, 2005. 